\title{
On 'the Scythian Theory': Reconstructing the Outlines of Johannes Elichmann's (1601/1602- 1639) Planned Archaeologia Harmonica
}

\author{
TOON VAN HAL \\ Research Foundation Flanders
}

The Leiden professors Claude de Saumaise (1588-1653) and Marcus Zuerius van Boxhorn (1612-1653) are generally credited with having developed the so-called Scythian hypothesis, considering 'Scythian' the matrix language of, among other languages, Latin, Greek, Persian, and Germanic. The present article aims to demonstrate that Johannes Elichmann (1601/1602-1639) gave the initial and decisive impetus to the development of the so-called Scythian theory. Elichmann, a Silesian physician who settled in Leiden, would have written an Archaeologia Harmonica had not death prevented him. A gifted and renowned expert of various oriental languages, he focused on the similarities between Persian and the Germanic languages. Based on the scarce sources available, Elichmann's views on language kinship will be reconstructed.

KEYWordS Elichmann, German, Persian, Salmasius, Scythian theory

Once Renaissance Europe had discovered Persia and its language, some striking lexical and even morphological similarities between Modern Persian and the Germanic languages became apparent to many Western scholars. Until the nineteenth-century emergence of comparative linguistics as an autonomous academic discipline, the

\footnotetext{
The present contribution is an adapted and expanded version of the paper read at the Annual Meeting of the Henry Sweet Society 2009 in Oxford. In addition, it elaborates on a small chapter devoted to Elichmann in Van Hal (2008). I am indebted to the helpful suggestions of the audience in Oxford. Comments by John Considine and Nicola McLelland on an earlier draft of this manuscript are gratefully acknowledged. Michael Squire was kind enough to proofread the text.
} 
Germanic languages were often considered to be closely related to Persian. The socalled 'Persian-German theory' constituted an unbroken line of continuity through more than two centuries of pre-comparative linguistics. Although some scholars were strongly opposed to the idea of a Persian-Germanic unity, many other scholars acknowledged (or were forced to acknowledge) that the similarities were impressive. Nevertheless, supporters of the Persian-German theory should not be regarded as a cohesive group, as they offered widely divergent explanations of these striking commonalities. The explanation most commonly offered was based on borrowings and contact, while an alternative theory regarded the parallels as remnants of the original lingua Adamica (see Van Hal, in press, for more details and further references). Without any doubt, the most significant breakthrough was achieved around I640, when some Leyden scholars integrated the Persian-German theory into the socalled Scythian theory. The Leiden professors Claude de Saumaise [Salmasius] (I588I653) and Marc[us] Zuer[ius] van Boxhorn[ius] (I6I2-I653) are generally credited with having developed this Scythian hypothesis, in which the 'Scythian' language was regarded as the matrix language of, among other languages, Latin, Greek, Persian, and Germanic, thus somehow foreshadowing later Indo-European linguistics. The present contribution, however, aims to demonstrate that the Silesian physician Johannes Elichmann (I60I/I602-I639) gave not only the initial but also the decisive impetus to the development of the Scythian theory, although his early death prevented him from publishing his ideas. Based on the scarce sources available, the article will reconstruct and assess Elichmann's views on language kinship. In contrast, Claude de Saumaise's views on Scythian, formulated in his De lingua Hellenistica (I643), will be shown to be mostly derivative.

As Elichmann published hardly anything during his short lifetime, his biography and intellectual outlook can only be reconstructed on the basis of indirect sources, particularly a number of early modern source types, which might require some introductory methodological notes. Most key references are offered in the (predominantly Latin) letter exchange between scholars in the so-called Respublica Litterarum (Bots \& Waquet, I997). The primary aim of many early modern letters was to communicate scholarly information on topical themes or to convey opinions on recent publications. To a certain extent, this subsection of letters (which were often eventually published by the author himself or by one of his colleagues) can therefore be compared to contemporary journals and reviews. Some letters written by a number of Elichmann's colleagues offer greater insight into his theories than the very few letters by Elichmann himself that have been preserved. Early modern alba amicorum and auction catalogues are additional (often neglected) types of sources that may shed new light on Elichmann's intellectual interests and network. An album amicorum was a small booklet in which the owner collected concise contributions or autographs by friends, authoritative professors, or renowned contemporary personalities. ${ }^{\mathrm{I}}$ Elichmann's album is currently preserved in the Wellcome Library in London (MS 257;

I The album became especially popular among travelling protestant students in Germany and the Low Countries, who primarily exploited it to display their extensive intellectual network (Blom, I98I; Heesakkers, 2000). 
cf. the formal description by Moorat, I962: I57-60). In addition, a catalogue of Elichmann's books was printed in I640, unsurprisingly one year after his death (Elichmann, I640b). When an illustrious scholar died, his library was usually sold at auction. On such occasions, small catalogues announcing the date and place of the auction as well as the objects put up for sale were distributed among potential purchasers. Hence, this source type deserves the attention of historiographers of scholarship as it enables them to (partly) reconstruct a scholar's library, which usually mirrors his scholarly interests (Van Selm, I987; Hoftijzer, I998; De Smet, 2002). Needless to say, alba as well as auction catalogues should be interpreted with caution.

Although it is beyond the scope of the present study to provide an updated biography (even though this would be useful, since the extant biographies ignore the sources listed above), ${ }^{2}$ some highlights of Elichmann's colourful and unconventional life will be sketched here. Born in I60I/I602, Johan[n][es] Elichman[n][us] (Elechmann, Eligman[nus], Heylichman, Elisman: even his album amicorum uses variant spellings), who is often confused with Ludovicus de Dieu (I590-I642) or Johann Eleman (another Leiden physician), seems regularly to have alternated or combined periods of study (medicine, Eastern languages, and probably philosophy) with periods of medical practice. Judging by the data included in his album amicorum, the originally Silesian intellectual led an extremely nomadic life, only settling in Regensburg (in Bavaria) and Liège (in today's Belgium) for somewhat longer periods. Johann Woestenraedt, one of his friends in Liège, seems to have shown him the way to Leiden, which was considered one of the most attractive and distinguished university towns in Europe among protestant students at that time. In Leiden, Elichmann studied Arabic with Jacob Golius, while also working as a physician. A champion of Arabic and other Eastern languages, Elichmann tried to visit Africa and eastern regions several times, but much to his regret, these plans never materialized. In I635, he stayed with the Danish physician Olaus Wormius (I588-I655), with whom he studied the Gothic language. Subsequently, he started to offer private lessons in Arabic. His students included Isaac Vossius, the son of the famous Gerardus Johannes Vossius (I577-I649), and Christian Ravius (Raue, I6I3-I677). In the same period, he established a firm reputation as a physician by saving the life of the renowned Claude de Saumaise, who had been given up by all other physicians, and by developing special pills that were enormously popular across Europe. However, before reaching the age of 40, Elichmann died somewhat unexpectedly on I8 August I639 after a short illness, without leaving a will. This generated considerable interest among his numerous friends and colleagues regarding the fate of his immense library in general and his manuscript legacy in particular. Elichmann's intellectual network looks impressive. Fully integrated in the Leiden milieu (Claude de Saumaise, Johannes de Laet, Jacobus Golius), he was in touch with, among many other scholars, Anna Maria

2 De Waard (I9II) and Juynboll (I93I: I9I-95) offer the best accounts now extant. See also Brown (I982) and De Nave (1986). I am preparing a new biographical article. 
van Schurman (I607-I678), Gerardus Johannes Vossius (I577-I649), Constantijn Huygens (I596-I678), Martin Opitz (I597-I639), René Descartes (I596-I650), Isaac Beeckman (I588-I637), and Marin Mersenne (I588-I648).

It is beyond doubt that Elichmann would have published his ideas, had he not died at such an early age. ${ }^{3}$ In a short, published letter addressed to his former professor of Arabic (Johannes Zechendorf, I580-I662), he stressed that a good command of Arabic was a considerable advantage for the study of medicine (Elichmann, I636). This suggests that Elichmann's interest in the Eastern languages, the elegance of which he praised (Elichmann, I640a: I42-43), should be seen in close connection with his professional curiosity as a physician. In I639, Elichmann took part in an ambitious project on 'the end of life' ('vitae terminus'), set up by the physician Johan van Beverwijk (I594-I647), in the third volume of which he elucidated the Persian and Arabic stances with regard to this issue (Beverovicius, I639). A year after his death, Saumaise published Elichmann's Arabic edition of the Tabula Cebetis (Graece, Arabice, Latine. Item aurea carmina Pythagorae; cf. Lutz, I979). In addition, Elichmann seems to have prepared an Arabic dictionary (cf. Saumaise's preface to Elichmann, I640a) and a Persian chronology, which may have circulated among early modern scholars (cf. Foy-Vaillant, I728: 33; Gronovius, I760: 687).

Interestingly, Elichmann would probably have published his linguistic views in a work entitled Archaeologia Harmonica, which was announced in Van Beverwijk (I639: I48). ${ }^{4}$ In a letter addressed to Peiresc, Saumaise stated that Elichmann mastered no fewer than sixteen languages (cf. below). In another letter, Saumaise wrote: 'Oultre sa langue maternelle et allemande, il entend, parle et escrit fort bon François et bon Italien. Il sçait la langue Arabique comme sa maternelle, et la Persienne, et n'est pas ignorant de la Turque' (Adam, I9I0: I08). Johan van Beverwijk provided

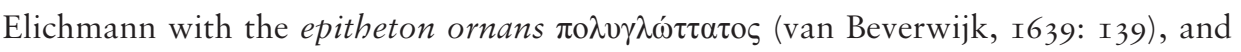
Ludovicus de Dieu described him as a helpful walking dictionary (I639: **2 $2-* * * 3 \mathrm{r}$ ). ${ }^{5}$ His expertise was not limited to Eastern languages; apart from Arabic and Persian (in which he had a near-native proficiency), he was well versed in more than ten other languages (most likely including Basque and some Scandinavian languages). It is safe to state that Elichmann was well informed on the precomparative endeavours thus far undertaken, since the auction catalogue of his library features the works of all important precomparative linguists, such as Philippus Cluverius, Adrianus Schrieckius, Goropius Becanus, Abraham Mylius, Josephus Justus Scaliger, and Johannes Isacius Pontanus (life-dates as in Droixhe, in this issue).

3 In a letter addressed to Theodoor Haack dated 24 November I639, Mersenne states: 'Le pauvre M. Elichmann promettoit beaucoup, s'il eust vescu davantage' (de Waard, I963: 636).

4 'nomina quidem ista nos in Archaeologia Harmonica ad unam reducimus originem'.

'In difficilioribus Dictionarii loco esset amicus noster praefatus [i.e. Elichmann], a quo non parum me in hoc opere adiutum fateor.' Probably Elichmann assisted de Dieu as well in writing his Persian Grammar (cf. de Bruijn, I996; Van Hal, 2009). Leiden University Library holds a letter in Spanish (Ms BPL 293 A) addressed to David le Leu de Wilhem (I588-I658), in which Elichmann refers to issues related to the study of Spanish. 
In what follows, I will attempt to reconstruct Elichmann's linguistic ideas, by first describing and then analysing the scarce testimonies still extant. In the earliest account known to me (2 September 1634), Saumaise described the linguistic views of his physician Elichmann in a letter addressed to Nicolas-Claude Fabri de Peiresc (I580-I637), an independent French scholar who was also intrigued by linguistic similarity:

Vos observations sur cette union et communion des langues, procedentes d'une mesme matrice, sont fort curieuses et tres belles ... dans laquelle persienne il a trouvé une si grande convenance avec sa germanique et thudesque, qu'il ne doubte point que la langue scythique ne soit la matrice de tous les dialectes qui ont esté en l'Europe, et dans une grande partie de l'Asie et de l'Orient. Il a amassé plus de cinq cens mots persans, qui sont tout à fait allemands: et dans la grammaire de l'une et l'autre langue, il a remarqué une telle ressemblance pour la terminaison des verbes, l'analogie des mots, et la syntaxe, qu'il faut necessairement juger qu'elles procedent toutes deux d'une mesme origine, qui est la scythique. Ces peuples ont autrefois inondé toute l'Europe et sont allez mesme jusqu'au fleuve Indus, et ont fait porter leur nom à une grande estendue de pays ès environs

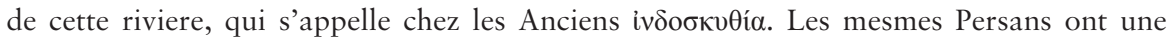
infinité de mots qui sympathisent avec les Grecs, mais touts ces mesmes se trouvent aussi dans la thudesque ou vieil saxon; ce qui monstre qu'ils viennent d'une mesme matrice. Il estudie à present la langue de Basques, dans laquelle il observe un merveilleux rapport de plusieurs paroles et à son celtique et à son persan. Nous en avons mesme chez nous [sc. in the French language] des mots tout purs persans, aussi bien qu'allemans; comme gourmand, est une diction entierement persique, car gour ou chour est à dire mangeaille, et mand est une addition qu'ils mettent à plusieurs vocables pour en faire

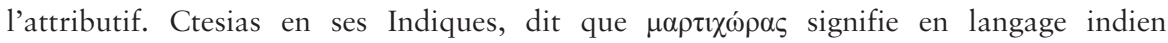

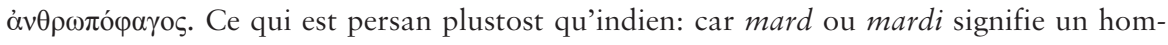
me, et chor ou chur mangeaille, et le verbe churdan, manger. Mais il peut estre aussi bien indien que persan. Je me suis aussi un peu adonné à cette langue depuis peu; à cause que tous les noms des simples dont se servent les Arabes, principalement ceux qui sont composés, sont quasi persans. (Bresson, I992: 386; Clementius, I656: I08-09)

A similar, yet less detailed account was delivered six years later, again by Saumaise, who sketched Elichmann's intellectual outlook in his preface to the posthumous edition of Tabula Cebetis:

With his particularly thorough knowledge of Arabic and Persian, he excelled in such a way that up to now only a very few scholars have gained better access to the secrets of those languages. As to Persian, Europe does not seem to have given birth to someone who is able to match him, and possibly it never will. He also found out - something which remains unknown to most of today's scholars - that Germanic and Persian are derived from the same origin. An innumerable number of words, shared by both languages, but also words with similar endings and composed in the same way, and many other arguments led him to this conjecture. In addition, since there are many words that can be found in Persian which are also Greek, but in such a way, however, that they seem 
equally to be Germanic, he supposed not without reason that the Greeks as well were highly indebted to the Scythian origin, which is the source from which both Persian and German originated. ${ }^{6}$

This is the only testimony to Elichmann's theory which is regularly mentioned in modern scholarship. However, two additional testimonies can also be cited. In a letter from 1635, Olaus Wormius offered the Icelandic scholar Arngrimus Jonas (I568-I648) some details of Elichmann's linguistic theory:

Last winter, the scholar Johann Elichmann stayed with me, a Silesian physician who has devoted himself entirely to the study of Eastern and Northern languages. He admires your work, and asked me to persuade you to publish the Apology (about which I had told him a lot). He would be very delighted to develop epistolary contacts with you, if I act as a mediator. He attaches much importance to our original language. He states that it has an extreme affinity with the Persian language - to such an extent that, in his opinion, it is a dialect of Persian. He supposes that those Asians who arrived here together with Otthinus were Persians, which he has promised to demonstrate. He hopes to draw much support from the original place names which are found in your Apology. Hence I wanted to write you this on his account. Now he is staying among the scholars of Leiden. He is a good-natured and a modest man. ${ }^{7}$

A last piece of evidence with regard to Elichmann's linguistic theories is offered by Ludovicus de Dieu in a letter addressed to James U[s]sher (I58I-I656), Church of Ireland Archbishop of Armagh.

I've been encouraged to this by the Silesian Johann Eligmann, who has been an acquaintance of mine for some years. He is a matchless Chemist, an outstanding physician, to whom our city was very much indebted during this plague. He is well versed in plenty of languages, among them Arabic and Persian, and I acknowledge that he was a great help to me in this work ... he has started a gradual comparison of the Germanic language in

6 'In Arabicae autem et Persicae linguae cognitione intima tantopere excelluit, ut pauci hactenus ad earum linguarum secreta penitius penetraverint. In Persica sane vix videtur Europa parem tulisse. Fortasse an nec feret. Quod ad hoc aevi latuit plerosque eruditorum, ex eadem origine compererat fluxisse Germanicam et Persicam linguam, ad hanc illum coniecturam ducente infinita vocum copia, utrique linguae communium, sed et verbis similiter terminatis, eodem modo compositis, aliisque multis argumentis. Quia porro multa quoque vocabula reperiuntur in Persico dialecto, quae et Graeca sunt, sed ita Graeca, ut etiam non minus videantur esse Germanica, ex eo non vane augurabatur, pluria etiam Graecos debuisse Scythicae origini, quo ex fonte tam Persica quam Germanica profluxisset' (Elichmann, I640a: 3).

7 'Fuit hieme praeterita apud me vir doctus, Johannes Elichmannus, Medicinae Doctor, Silesius, qui totum se dedit linguis orientalibus et Arctois excolendis, et tua impense aestimat, et, ut ad Apologiam (de qua ipsi multa dixi) edendam hortarer, petiit. Is tecum familiaritatem per litteras colere, me mediatore, gestit. Priscae nostrae linguae multum tribuit, et cum Persica summam habere affinitatem ait, adeo ut eius dialectum arbitretur, et Asianos istos, qui huc cum Otthino venerunt, Persas fuisse suspicetur, quod se demonstraturum promisit. Ex priscis locorum nominibus, quae tua exprimit Apologia, se multum subsidii habiturum sperat. Quocirca eius rogatu haec scribere volui. Iam inter Literatores Lugduni Batavorum degit, vir candidus et modestus' (Wormius, I75I: nr 332; Benediktsson, I948). 
all its dialects, and also of Latin and Greek, with the Persian language. Persian shares with those languages, and particularly with Germanic and our Dutch language, an affinity which, as I have been shown, is very great. Hence, he also wants to investigate the character of Irish; this language might turn out to be closer to Persian than the others. ${ }^{8}$

Elichmann had asked his friend de Dieu to get in touch with Ussher in order to acquire an Irish lexicon. Much to his disappointment, Ussher replied on 4 January I637 that a printed Irish dictionary was still lacking: in contrast to the flourishing lexicography in other European languages, Ireland had not yet started its modern lexicographic activity. Ussher, whose role in making Irish-language materials available to Continental scholars was of real significance (cf. Leerssen, I982-83: 58), provided him with an Irish alphabet and an Irish translation of the New Testament, instead of a dictionary.

It is not inconceivable that additional testimonies to Elichmann's linguistic theory will come to light thanks to the growing number of electronic resources offering digitized early modern sources, which will enable us to refine the initial findings. A first conclusion that can be inferred from the statements made by Saumaise, Worm, and de Dieu is that all of them held Elichmann's comparative endeavours in high esteem. This is by no means self-evident, since linguistic adventurism was often met with disdain, irrespective of how promising certain ideas might look to us today. So, for instance, the rather far-fetched ideas put forward by Johannes Goropius Becanus, who was nevertheless respected as a physician, were widely thought ridiculous. Marcus Zuerius van Boxhorn's Scythian theory often underwent a similar fate, although this Leiden scholar would later be proclaimed (albeit a little too zealously) the 'first historical linguist' by Jack Fellman (I974). In addition, Elichmann, whose intellectual thirst for knowledge must have been unquenchable, seemed determined to write a book on the similarities between a certain number of languages (Archaeologia Harmonica). Undoubtedly, Persian played a pivotal role in his linguistic model, given that the importance of this language in this connection is stressed in all testimonies. With some caution, one could conclude that both Persian and German(ic) were of vital importance in his comparative project, with the study of other European and some other Asian languages playing a subsidiary role. It is, however, still more important to observe that Elichmann accounted for the linguistic similarities in

8 'Incitavit ad haec, quem ab aliquot annis familiarem habui, Johannes Eligmannus Silesius, chymicus incomparabilis, medicus eximius, et de nostra urbe durante hac lue optime meritus, plurimarum linguarum, et inter eas Arabicae ac Persicae bene peritus, quem magno mihi in hoc opero adiumento fuisse fateor ... coeperit paulatim linguam Germanicam per omnes eius dialectos, Latinam item et Graecam cum Persica conferre, quippe quae cum istis, praesertim cum Germanica nostraque Belgica ingentem, quod experti loquimur, affinitatem habeat, Irlandicae quoque genium explorare cupit, si haec fortassis propius ceteris ad eam accedat' (ed. Elrington, I864: II-I4).

9 'Quominus autem ipsius desiderio de dictionario Hibernico satisfacere possim, hoc in causa est, quod nullum adhuc habeamus lexicon sive per se factum, sive cum alia lingua comparatum, saltem non typis editum. Alphabetum tamen Hibernicum atque integrum Novum Testamentum una cum hisce transmitto' (Elrington, I864: 24-25; a new edition of Ussher's correspondence by Elizabethanne Boran is under way). 
terms of a common origin. In contrast to prevailing explanations, he was convinced that the parallels between Persian, German, and the other languages should be attributed to a common Scythian origin. In assigning the label 'Scythian', the coverage of which was wide ranging and extensive (Villani, 2003), to a limited number of languages (although a specialist in Arabic as well, he did not intend to include Arabic or Hebrew in his theory), he paved the way for the later concept of the IndoEuropean language group more than any previous scholar. Obviously, Elichmann's construction did not entirely match the modern idea of the Indo-European language group, given that he seemed eager to also adopt Basque as a Scythian language. His argumentation is not exclusively based on lexical items, particularly proper names, but relies on grammatical and syntactical properties as well. Remarkable as well is the Indian perspective, as suggested by his reference to Indoscythia in Saumaise's letter to Peiresc. In this connection, one could object that Saumaise, who is often credited with having introduced the Scythian theory, presumably explained Elichmann's ideas within his own, original 'Scythian' framework, as he was the only scholar to have situated Elichmann's ideas within a Scythian framework. As a matter of fact, neither Wormius nor de Dieu referred to the Scyths and Indoscythia. Wormius's letter even suggests that Elichmann tended to regard all languages cognate to Persian as dialects of the Persian language. All the same, this scenario is fairly implausible for several reasons. First, Saumaise's book De Hellenistica commentarius, in which he elaborated on the Scythian theory, appeared four years after Elichmann's death and almost ten years after Saumaise's letter to Peiresc. Moreover, Elichmann did mention the Scythian origin of the Persians, albeit very succinctly. ${ }^{\text {IO }}$ In addition, Saumaise's discussion of the Scythian theory seems to be a mere aside in his work on the origins of the Greek language (cf. the contribution in this issue by John Considine, who also cites some later scholars suggesting Saumaise's indebtedness to Elichmann). More revealingly, Saumaise explained the parallels between Greek and Persian in one of his earlier works as Persian borrowings from Greek. ${ }^{\text {II }}$ Although De Hellenistica commentarius turned out to be crucial for the dissemination of the Scythian theory (cf. Muller, I984 for Saumaise's influence on Monboddo), its author was largely dependent on Elichmann's linguistic ideas, although it is impossible to determine whether the Scythian reconstructions of some numerals, as they appear in Saumaise (I643: $384 \mathrm{ff}$. ), constituted Saumaise's original

\footnotetext{
Io 'Si Persas tandem, qui Scythicae sunt originis' (van Beverwijk, I639: I44).

II 'Infinita hodie habent vocabula Persae, quae de Graeco manasse is demum potest dubitare qui omnia ignorat. Rubinum vocant Yacut; ex nomine úớkıvoç. Band dicunt fasciam. Id ex Graeco Bóvôov postremi Imperii, quod a Latino factum est bandum ... Hinc bandum pro vexillo. Glossae: "Bandon, ó́yvov". Inde et nos Francoceltae Bandam pro fascia dicimus, et bandare pro fasciare, quod tamen a Persis non didicimus, sed inde prorsus unde et Persae habuimus ... Nec Persicam ab antiquo originem melius redolent eae voces quibus hodie Persae matrem, fratrem et sororem appellant: quas et Germanicae dialecto communes esse miratur Scaliger. Ego non miror. Nam et Persae a Graecis eas acceperunt: Germani a Latinis, qui easdem habuere cum Graecis. Germanos

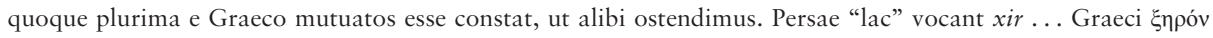
et '̇npíov id appellant. Atque inde Persicum' (Saumaise, I629: II30).
} 
contribution to the theory or not. Marcus Zuerius van Boxhorn, who developed his own version of the Scythian theory, must have been initially indebted either to Elichmann or to Saumaise. As a Leiden professor, he is highly unlikely to have invented a similar theory entirely independent of his Leiden colleagues Elichmann and/or Saumaise. ${ }^{\mathrm{I} 2}$

Unsurprisingly, Elichmann's name was before long eclipsed by Salmasius', although some early authors certainly mentioned his comparative endeavours (cf., for instance, the Swedish Orientalist Gustave Peringerus, I674: 37). The journal Neue Zeitungen von Gelehrten Sachen Auf das Jahr I7I9 (X: 80) even announced a book composed by Johann Hager entitled De convenientia linguae Persicae et Germanicae, ea methodo, qua Elichmannus ... voluit pertractare. This work, however, was never published. ${ }^{13}$ Gottfried Wilhelm von Leibniz (I646-I7I6) was also indirectly familiar with Elichmann's views. Whereas Leibniz firmly supported the theory at an early stage of his scholarly investigations, ${ }^{14}$ his support later seems to have weakened, as emerges from a letter sent to the Orientalist Hiob Ludolf (2I March I695), in which he states that he could not find as many similarities between the Persian and German language as specialists like Elichmann. ${ }^{\mathrm{I}}$ Apart from that, it is also well known that Leibniz put forward the concept of the so-called Japhetic language group, consisting of languages now known as Indo-European, which he contrasted with the so-called Aramaic languages (now generally known as Semitic). ${ }^{16}$ The present article aimed at demonstrating that several decades earlier a similar subdivision had been put forward by Johannes Elichmann.

\section{References}

Adam, Charles. I910. Vie et ceuvres de Descartes: étude historique. Paris: Cerf.

Benediktsson, Jakob. ed. I948. Ole Worm's Correspondence with Icelanders. Copenhagen: Munskgaard.

Beverwijk, Johan van. ed. I639. Epistolica quaestio de vitae termino, fatali an mobili? Cum doctorum responsis. Pars tertia, et ultima, nunc prima edita. Seorsim accedit ... Annae Mariae a Schurman de eodem argumento

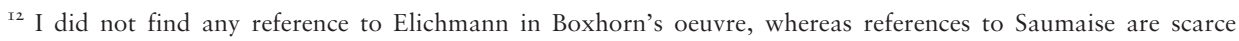
(probably due to inimicitia academica; cf. Droixhe, I989).

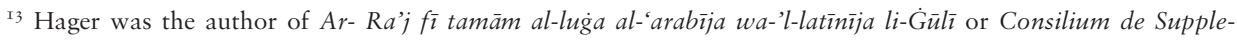
mento Lexici Arabico-Latini Goliani, cum specimine spicilegii propositum (Vitembergae: Typis Christiani Schroederi, I7I9). Von Seelen (I720: II7) cryptically and erroneously referred to Hager's announced work ('Vid. Relatt. Nov. de Rebus Litterar. I719. n. I9'. [instead of n. I0] p. 80). This erroneous reference was adopted by Dorn (I827: 97). I am indebted to Thomas Habel (Index deutschsprachiger Rezensionszeitschriften des I8. Jahrhunderts of the Akademie der Wissenschaften zu Göttingen) for deciphering this reference.

${ }^{14}$ Cf. his Histoire de Bronsvic (I692) (Leibniz, 2004: 842-43) as well as small references in letters sent to Ludolf on 25 July I692 (Leibniz, I970: 360-62) and to Daniel Larroque on 26 January I694 (Leibniz, I979: 248-5I).

I5 'Putabam Salmasii et aliorum testimonio magnam esse cognationem linguae Germanicae et Persicae; sed cum aliquando Gazophylacium Persicum inspexissem, spe pauciora reperi, quae faverent. Oportet ergo, cognationem illam magis, ut saepe fit, in occulto latere, non facile nisi Elichmanno et similibus interiora linguae doctis apparituram' (Leibniz, I982: 360-64). A similar statement was made in his Unvorgreiffliche Gedancken (c. 1697) and in his Brevis designatio meditationum de originibus gentium ductis potissimum ex indicio linguarum (I7IO).

${ }^{16}$ The innovation lies in the sharp divide drawn between both groups rather than in the term 'Japhetic', which was frequently used among early modern scholars, albeit with divergent coverages. 
epistola, totius disputationis terminus; item eiusdem argumenti alia a Joanne Elichmanno ... ex mente et monimentis Arabum et Persarum contexta. Lugdunum Batavorum: ex officina Ioannis Maire.

Blom, Franciscus Joannes Maria. 198I. Christoph and Andreas Arnold and England: the travels and bookcollections of two seventeenth-century Nurembergers. Doctoral dissertation, KU Nijmegen.

Bots, Hans \& Waquet, Françoise. I997. La république des lettres. Paris: Belin.

Bresson, Agnès. I992. Nicolas-Claude Fabri de Peiresc: Lettres à Claude Saumaise et à son entourage (I620-I637). Florence: Olschki.

Brown, Barbara. 1982. Ussher and his European Contemporaries: Some Manuscripts at Dublin. Nouvelles de la république des lettres, I: 71-90.

Clementius, Antonius. ed. 1656. Claudii Salmasii ... Epistolarum liber primus. Accedunt, De laudibus et vita eiusdem, prolegomena. Lugduni Batavorum: ex typographia Adriani Wyngaerden.

de Bruijn, Johannes T. P. I996. Dieu, Louis (Ludovicus) de. In: Eshan Yarshater, ed. Encyclopaedia Iranica, vol. 7. New York: Bibliotheca Persica, pp. 397-98.

de Dieu, Louis de. ... Historia Christi persice conscripta, simulque multis modis contaminata, a P. Hieronymo Xavier Soc. Jesu. Lvgdvni Batavorvm: ex officina Elseviriana.

De Nave, Francine. 1986. Philologia Arabica: Arabische studies en drukken in de Nederlanden in de I6de en I7de eeuw. Antwerpen: Museum Plantin-Moretus.

De Smet, Rudolf, ed. 2002. Les humanistes et leur bibliothèque. Leuven: Peeters.

de Waard, Cornelis. r9ı. Elichman (Dr Johan). In: Philipp Christiaan Molhuysen \& Dirk Peter Blok, eds. Nieuw Nederlandsch Biografisch Woordenboek, vol. I5. Leiden: Sijthoff's Uitgevers-Maatschappij, pp. 80I-02.

- I963. Correspondance du P. Marin Mersenne, religieux minime. VIII: Août I638-Décembre I639, vol. I. Paris: Éditions du Centre National de la Recherche Scientifique.

Dorn, Boris Andreevich. I827. Über die Verwandtschaft des persischen, germanischen und griechisch-lateinischen Sprachstammes. Hamburg: Meissner.

Droixhe, Daniel. 1989. Boxhorn's Bad Reputation: A Chapter in Academic Linguistics. In: Klaus D Dutz, ed. Speculum historiographiae linguisticae: Kurzbeiträge der IV. Internationalen Konferenz zur Geschichte der Sprachwissenschaften. Münster: Nodus, pp. 359-84.

Elichmann, Johannes. 1636. Literae exoticae, scriptae Arabice. Ab eodem in literas Hebraeas conversae punctatae et ferme ad verbum in Latinum versae / a Joanne Elichmannus ad Joannem Zechendorff. Jenae: Lippold.

- I640a. Tabula Cebetis Graece, Arabice, Latine. Item aurea carmina Pythagorae. Lugduni Batavorum: Typis Iohannis Maire.

- I640b. Catalogus variorum ac rarissimorum in qualibet scientia, ac lingua librorum ... Johannis Elichmanni ... qui vendentur in aedibus Francisci Hackii, bibliopolae, ad diem Jovis, 24 Maii [I640]. Lugduni Batavorum: apud Johannem Jansonium al̀ Dorp.

Elrington, Charles Richard. I864. The Whole Works of the Most Rev. James Ussher, vol. I6. Dublin: Hodges, Smith.

Fellman, Jack. 1974. The First Historical Linguist. Linguistics, 4I: 3I-33.

Foy-Vaillant, Jean. I728. Arsacidarum imperium sive regum Parthorum historia. Parisiis: Moette.

Gronovius, Abraham. ed. I760. Iustini Historiae Philippicae. Lugduni Batavorum: apud Samuelem et Joannem Luchtmans.

Heesakkers, Christiaan Lambert. 2000. Een netwerk aan de basis van de Leidse universiteit: Het album amicorum van Janus Dousa. Leiden: Universiteitsbibliotheek Leiden.

Hoftijzer, Paul G. I998. The Library of Johannes de Laet (I58I-I649). Lias, 25(2): 20I-I6.

Juynboll, Wilhelmina Maria Cornelia. I93I. Zeventiende-eeuwsche beoefenaars van het Arabisch in Nederland. Utrecht: Kemink.

Leerssen, Joep. I982/83. Archbishop Ussher and Gaelic culture. Studia Hibernica, 22-23: 50-58.

Leibniz, Gottfried Wilhelm. I970. Allgemeiner politischer und historischer Briefwechsel. Herausgegeben von dem Leibniz-Archiv der niedersächsischen Landesbibliothek Hannover. Achter Band I692. Berlin: Akademie.

- 1979. Allgemeiner politischer und historischer Briefwechsel. Herausgegeben von dem Leibniz-Archiv der niedersächsischen Landesbibliothek Hannover. Zehnter Band I694. Berlin: Akademie.

- I982. Allgemeiner politischer und historischer Briefwechsel. Herausgegeben von dem Leibniz-Archiv der niedersächsischen Landesbibliothek Hannover. Elfter Band Januar-Oktober I695. Berlin: Akademie. 
- 2004. Schriften und Briefe zur Geschichte, ed. by Malte-Ludolf Babin and Gerd van den Heuvel. Hannover: Hahnsche Buchhandlung.

Lutz, Cora E. 1979. The Salmasius-Elichmann Edition of the 'Tabula' of Cebes. Harvard Library Bulletin, 27(2): I65-7I.

Moorat, Samuel A. J. 1962. Catalogue of Western Manuscripts on Medicine and Science in the Wellcome Historical Medical Library. London: Wellcome Historical Medical Library.

Muller, Jean-Claude. I984. Saumaise, Monboddo, Adelung: Vers la grammaire comparée. In: Sylvain Auroux, Michel Glatigny, André Joly \& Anne Nicolas, eds. Matériaux pour une histoire des théories linguistiques. Essays toward a History of Linguistic Theories. Materialien zu einer Geschichte der Sprachwissenschaftlichen Theorien. Lille: Presses Universitaires, pp. 389-96.

Peringer[us], Gustavus. 1674. Concio laudibus ac eulogiis nobiliorum in Orbe Eoo idiomatum dicta in Athenaeo Upsalensi Septemtrionalium principe XV Cal. Quinctil. Anni Christiani MDCLXXIV. Stockholmae: Literis ac operis Nicolai Wankiif.

Saumaise, Claude de. I629. Plinianae exercitationes in Caii Julii Solini Polybistora. Item Caii Julii Solini Polybistor ex veteribus libris emendatus. Parisiis: apud Hieronymum Drouart.

- I643. De Hellenistica commentarius, controversiam de lingua Hellenistica decidens et plenissime pertractans originem et dialectos Graecae linguae. Lugd[uni] Batavor[um]: ex officina Elseviriorum.

Van Hal, Toon. 2008. 'Moedertalen en taalmoeders': methodologie, epistemologie en ideologie van het taalvergelijkend onderzoek in de renaissance, met bijzondere aandacht voor de bijdrage van de humanisten uit de Lage Landen. Unpublished dissertation, Catholic University Leuven. Published version in press: Brussels: Koninklijke Vlaamse Academie voor Wetenschappen en Kunsten.

- 2009. Jerónimo Xavier S. J., Historia Christi persice conscripta (I639). In: Paul Begheyn, Bernard Deprez, Rob Faesen, Leo Kenis \& Eddy Put, eds. Jesuit Books in the Low Countries, 1540-I773: A Selection from the Maurits Sabbe Library. Leuven: Maurits Sabbe Library, Faculty of Theology; Peeters, pp. 96-99.

—. in press. Early Stages of Persian-German Language Comparison. In: Gerda Haßler, ed. History of Linguistics 2008: Selected Papers from the Eleventh International Conference on the History of the Language Sciences (ICHoLS XI), 28th August-2nd September 2008, Potsdam. Amsterdam: Benjamins.

Van Selm, Bert. 1987. Een menighte treffelijcke boecken: Nederlandse boekhandelscatalogi in het begin van de zeventiende eeuw. Utrecht: HES.

Villani, Francesco Paolo. 2003. Scythae. Un problema linguistico, etnografico e culturale dell'età moderna. Linguistica, I: 443-91.

Von Seelen, Jo. Henr. ed. I720. Marcus Zuerius Boxhornius, Epistola de Persicis Curtio memoratis vocabulis, eorumque cum Germanicis cognatione notis instructa. Lubeccae: apud Petrum Boeckmannum.

Wormius, Olaus. I75I. Olai Wormii et ad eum doctorum virorum epistolae: medici, anatomici, botanici, physici et historici argumenti. Havniae: s.e.

\section{Notes on contributor}

Toon Van Hal is affiliated as a postdoctoral researcher of the Research Foundation Flanders (FWO-Vlaanderen) to the Catholic University of Leuven and to the University of Potsdam. He publishes on the genealogical views on languages held by Dutch and German (post-) Renaissance scholars.

Correspondence to: Toon Van Hal, Faculteit Letteren, Katholieke Universiteit Leuven, Blijde-Inkomststraat 2I b. 3318, 3000 Leuven, Belgium. E-mail: toon. vanhal@arts.kuleuven.be 